\title{
CHANGING STUDENTS' ATTITUDES, SATISFACTION AND INTENTIONS OF SERVICE-LEARNING IN MIS COURSES
}

\author{
Su-Houn Liu, Chung Yuan Christian University, vandy@mis.cycu.edu.tw \\ Hsiu-Li Liao, Chung Yuan Christian University, wenlly@mis.cycu.edu.tw
}

\begin{abstract}
Service-learning courses offer department of management information systems (MIS) students the opportunity to create and implement systems in realworld, public service-oriented social contexts. Students provide government and non-profit agencies information systems services and solutions via the community service activity. The survey was conducted on 146 students who were enrolled in a system analysis and software development ( $S A \& S D)$ course in an MIS department at a comprehensive university. The student subjects were divided into two groups by their class. After they finished the course, the students were asked to complete a questionnaire. The analytical results of our investigation indicate service learning adoption model has differences between service-learning and non-service-learning students. Those interested in promoting service learning may find these results helpful in guiding their efforts.
\end{abstract}

Keywords: Service Learning, Civic Attitudes and Skills, Course Satisfaction, Intentions

\section{INTRODUCTION}

Integration of service-learning experiences into higher education has been occurring for decades. Service-learning delivers on the learning objectives of the course (for which the student has contracted) via the community service activity just as an exam or paper does. Because so much of Information Management course content is skill based, service- learning provides IS professors with an excellent vehicle for teaching course content in a hands-on environment. By doing that, service-learning has the potential to fulfill many goals in Information Management education. It is an excellent way to reflect current business practices, reinforce classroom learning through an experiential activity, and increase the students' skill base. Research generally indicates that students engaged in service learning increase in problem-solving skills [7], build student skill levels [1] develop leadership skills [4], and foster social responsibility [3,5]. Therefore, the research integrated the constructs of the Civic Attitudes and Skills Questionnaire (CASQ) into the service learning adoption model.

Most service learning research take its position from an instructors' point of view and identifies service learning as an effective teaching method. This study tries to address the issue from the students' point of view. If student are not satisfied, they will not be compelled to take more courses with service learning requirements. The researchers of this study believed that it is crucial that students are not only passively accepted, but also that they develop intention and commitment to engage in this increasingly important learning methodology.

\section{The Research Model}

Figure 1 illustrates the Research Model empirically tested in this study. This model was constructed to answer the research questions raised earlier and is derived from the theory described in the section.

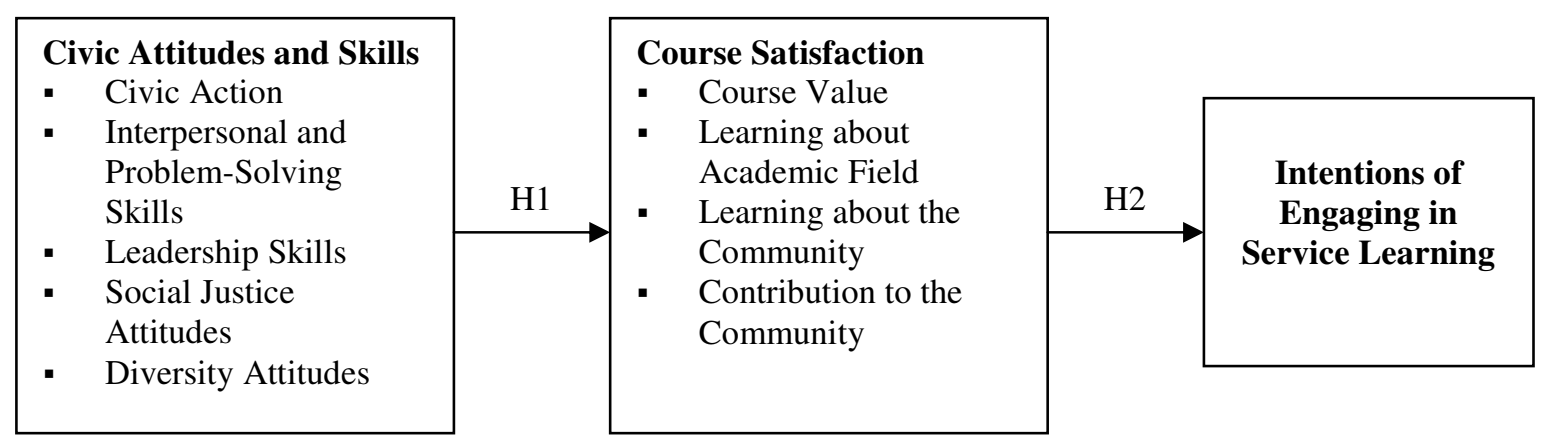

Figure 1. Research Model 
Research Variables and Definitions

- Civic action: to evaluate students' intentions to engage in community service.

- Interpersonal and problem-solving skills: to evaluate students' abilities to work cooperatively, think logically, analytically, and solve problems.

- Leadership skills: to evaluate students' abilities to lead a group of people.

- Social justice attitudes: degree to which students agree with the causes of poverty and misfortune.

- Diversity attitudes: to describe students attitudes toward diversity and their interests in culturally different people.

- Course value: to evaluate how important or useful material in the course had been.

- Learning about academic field: degree to which students understand and apply the course concepts and interest in the field.

- Learning about the community: to evaluate how much students had learned about the community.

- Contribution to the community: to indicate students' perceptions of how useful their service activities had been in the community.

\section{Hypotheses}

A series of testable hypotheses were developed from the proposed research model, as shown below:

H1: Students' civic attitudes and skills are related to their course satisfaction.

H2: Students' course satisfaction is related to their intentions of engaging in service learning.

H3: Service learning adoption model have differences between service-learning and nonservice-learning students.

Table 1. Scale Reliabilities

\begin{tabular}{|c|c|c|c|c|c|}
\hline Scale & $\begin{array}{c}\text { Number of } \\
\text { Items }\end{array}$ & $\begin{array}{c}\text { Reliability for } \\
\text { our Sample }\end{array}$ & Scale & $\begin{array}{c}\text { Number of } \\
\text { Items }\end{array}$ & $\begin{array}{c}\text { Reliability for } \\
\text { our Sample }\end{array}$ \\
\hline Civic Action & 6 & 0.9328 & Course Value & 7 & 0.9177 \\
\hline $\begin{array}{l}\text { Interpersonal and } \\
\text { Problem-Solving Skills }\end{array}$ & 6 & 0.8823 & $\begin{array}{l}\text { Learning about } \\
\text { Academic Field }\end{array}$ & 5 & 0.8951 \\
\hline Leadership Skills & 3 & 0.8299 & $\begin{array}{l}\text { Learning about the } \\
\text { Community }\end{array}$ & 5 & 0.8898 \\
\hline Social Justice Attitudes & 4 & 0.7676 & $\begin{array}{l}\text { Contribution to the } \\
\text { Community }\end{array}$ & 4 & 0.8732 \\
\hline Diversity Attitudes & 3 & 0.8507 & Intentions & 3 & 0.9194 \\
\hline
\end{tabular}

Factor analysis also confirmed that the construct validity of the scales could be performed adequately. Using the principal components method with varimax rotation, construct validity was examined. Table 2 reports the factor loadings, and explained variance

\section{METHODOLOGY}

\section{The Sample and Study Context}

The survey was conducted on 146 students who were enrolled in a system analysis and software development (SA \& SD) course in an MIS department at a comprehensive university. The student subjects were divided into two groups by their class. After they finished the course, the students were asked to complete a questionnaire. Completion of the survey was voluntary. A total of 133 surveys were completed, with 127 usable responses returned, resulting in a response rate of $86 \%$. Engaging in service learning was completed by 56 students, while 71 indicated that they were not doing service learning. The age range of the sample was 20-30 years old. Of the 127 respondents, 73 were females and 54 were males. None of the subjects had any prior service learning experiences. Service was schools, hospitals, farms, government agencies and nonprofit agencies.

\section{Measures}

Table 1 shows the number of items comprising each scale and Cronbach's alpha for scale reliability obtained for our sample. Factor reliabilities were between 0.8299 and 0.9328 for each factor. Reliability from our sample showed a reasonable level of reliability $(\alpha>0.7)$. carried out at 22 different community sites, including for each of the factors. Bagozzi and Yi [2] suggested that factor loadings for each item be over 0.6. The factor loadings for all items exceeded 0.655 and indicated that the individual items also had discriminant validity. 
Table 2. Summary Statistics and Factor Loadings for all Constructs
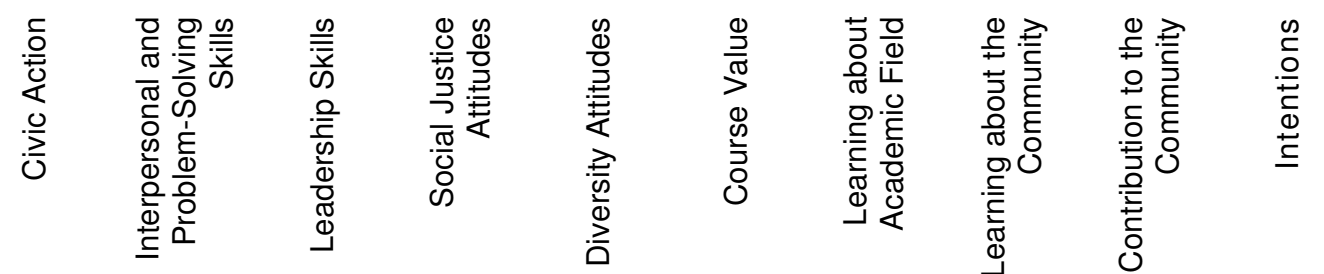

\begin{tabular}{|c|c|c|c|c|c|c|c|c|c|c|}
\hline Civic Action & $\begin{array}{l}0.929 \\
0.912 \\
0.914 \\
0.860 \\
0.850 \\
0.724\end{array}$ & & & & & & & & & \\
\hline $\begin{array}{l}\text { Interpersonal } \\
\text { and Problem- } \\
\text { Solving Skills }\end{array}$ & & $\begin{array}{l}0.829 \\
0.843 \\
0.772 \\
0.837 \\
0.773 \\
0.707\end{array}$ & & & & & & & & \\
\hline $\begin{array}{l}\text { Leadership } \\
\text { Skills }\end{array}$ & & & $\begin{array}{l}0.931 \\
0.896 \\
0.756\end{array}$ & & & & & & & \\
\hline $\begin{array}{l}\text { Social Justice } \\
\text { Attitudes }\end{array}$ & & & 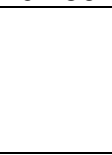 & $\begin{array}{l}0.655 \\
0.787 \\
0.822 \\
0.822 \\
\end{array}$ & & & & & & \\
\hline $\begin{array}{l}\text { Diversity } \\
\text { Attitudes }\end{array}$ & & & & & $\begin{array}{l}0.905 \\
0.890 \\
0.836\end{array}$ & & & & & \\
\hline Course Value & & & & & & $\begin{array}{l}0.729 \\
0.884 \\
0.848 \\
0.891 \\
0.918 \\
0.842 \\
0.708\end{array}$ & & & & \\
\hline $\begin{array}{l}\text { Learning } \\
\text { about } \\
\text { Academic } \\
\text { Field }\end{array}$ & & & & & & & $\begin{array}{l}0.815 \\
0.836 \\
0.869 \\
0.842 \\
0.847\end{array}$ & & & \\
\hline $\begin{array}{l}\text { Learning } \\
\text { about the } \\
\text { Community }\end{array}$ & & & & & & & & $\begin{array}{l}0.748 \\
0.861 \\
0.824 \\
0.878 \\
0.853\end{array}$ & & \\
\hline $\begin{array}{l}\text { Contribution } \\
\text { to the } \\
\text { Community }\end{array}$ & & & & & & & & oroco & $\begin{array}{l}0.802 \\
0.893 \\
0.887 \\
0.822 \\
\end{array}$ & \\
\hline Intentions & & & & & & & & & & $\begin{array}{l}0.935 \\
0.948 \\
0.904 \\
\end{array}$ \\
\hline
\end{tabular}




\section{RESULTS AND DISCUSSION}

Pearson correlation coefficients for all research variables are shown in Table 4. Although Table 3 indicates that most user perceptions are significantly correlated with each other, an examination of the variance inflation factors indicated that the multicollinearity was not significant [6]. Hence, residual analysis was also conducted to verify the assumptions underlying stepwise regression analysis. All assumptions were confirmed.

Table 3. Pearson Correlation Coefficients
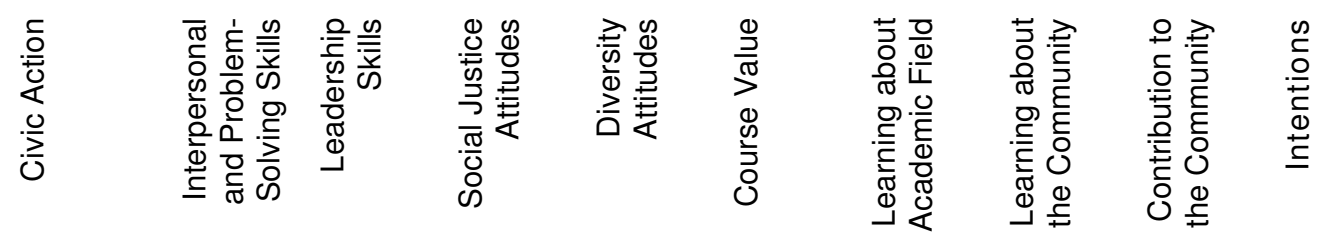

\begin{tabular}{|c|c|c|c|c|c|c|c|c|c|c|}
\hline Civic Action & 1.000 & & & & & & & & & \\
\hline $\begin{array}{l}\text { Interpersonal } \\
\text { and Problem- } \\
\text { Solving Skills }\end{array}$ & $0.287^{\star \star \star}$ & 1.000 & & & & & & & & \\
\hline $\begin{array}{l}\text { Leadership } \\
\text { Skills }\end{array}$ & $0.334^{\star \star \star}$ & $0.328^{\star \star *}$ & 1.000 & & & & & & & \\
\hline $\begin{array}{l}\text { Social Justice } \\
\text { Attitudes }\end{array}$ & 0.115 & $0.306^{\star * \star}$ & 0.041 & 1.000 & & & & & & \\
\hline $\begin{array}{l}\text { Diversity } \\
\text { Attitudes }\end{array}$ & 0.033 & 0.092 & 0.110 & $0.215^{\star \star}$ & 1.000 & & & & & \\
\hline Course Value & $0.326^{\star \star \star}$ & $0.334^{\star \star \star}$ & $0.238^{\star \star \star}$ & $0.373^{\star \star \star}$ & 0.125 & 1.000 & & & & \\
\hline $\begin{array}{l}\text { Learning } \\
\text { about } \\
\text { Academic } \\
\text { Field }\end{array}$ & $0.390^{\star \star \star}$ & $0.425^{\star \star \star}$ & $0.257^{\star \star \star}$ & $0.303^{\star \star \star}$ & $0.158^{*}$ & $0.772^{\star \star \star}$ & 1.000 & & & \\
\hline $\begin{array}{l}\text { Learning } \\
\text { about the } \\
\text { Community }\end{array}$ & $0.280^{* * *}$ & $0.431^{\star * *}$ & $0.151^{*}$ & $0.296^{* * *}$ & $0.225^{\star \star}$ & $0.472^{* * *}$ & $0.666^{\star \star \star}$ & 1.000 & & \\
\hline $\begin{array}{l}\text { Contribution } \\
\text { to the } \\
\text { Community }\end{array}$ & $0.426^{\star \star \star}$ & $0.382^{* \star *}$ & $0.173^{\star}$ & 0.145 & $0.180^{\star \star}$ & $0.440^{\star \star \star}$ & $0.578^{\star \star \star}$ & $0.627^{* \star \star}$ & 1.000 & \\
\hline Intentions & $0.581^{\star \star \star}$ & $0.197^{\star *}$ & 0.046 & $0.179^{\star \star}$ & $0.230^{\star * \star}$ & $0.398^{\star \star \star}$ & $0.442^{\star \star \star *}$ & $0.424^{\star \star \star}$ & $0.624^{\star \star \star}$ & 1.000 \\
\hline
\end{tabular}

The next step in the analysis was to test the significance of the individual terms in the model. These tests correspond to $\mathrm{H} 1-\mathrm{H} 3$. The null hypotheses tested, the $\mathrm{t}$ statistic, and significance levels are illustrated in Figure 2, as is whether the hypotheses were supported. Civic action, interpersonal and problem-solving skills, and social justice attitudes are positively associated with course value and learning about academic field. Civic action and interpersonal and problem-solving skills are positively related to learning about the community and contribution to the community. Besides, diversity attitudes significantly influence learning about the community and contribution to the community. Course value and contribution to the community positively influence students engaging in service learning intentions. $\mathrm{H} 1$ and $\mathrm{H} 2$ are partially supported.

Figure 3 and 4 graphically illustrate the significant relationships found in our study. For non-servicelearning students, social justice attitudes significantly and directly influence course value and learning about academic field. Interpersonal and problemsolving skills are positively associated with learning about academic field, learning about the community and contribution to the community. Only contribution to the community has a directly and positive influence on students' intentions of engaging in service learning in the future. 


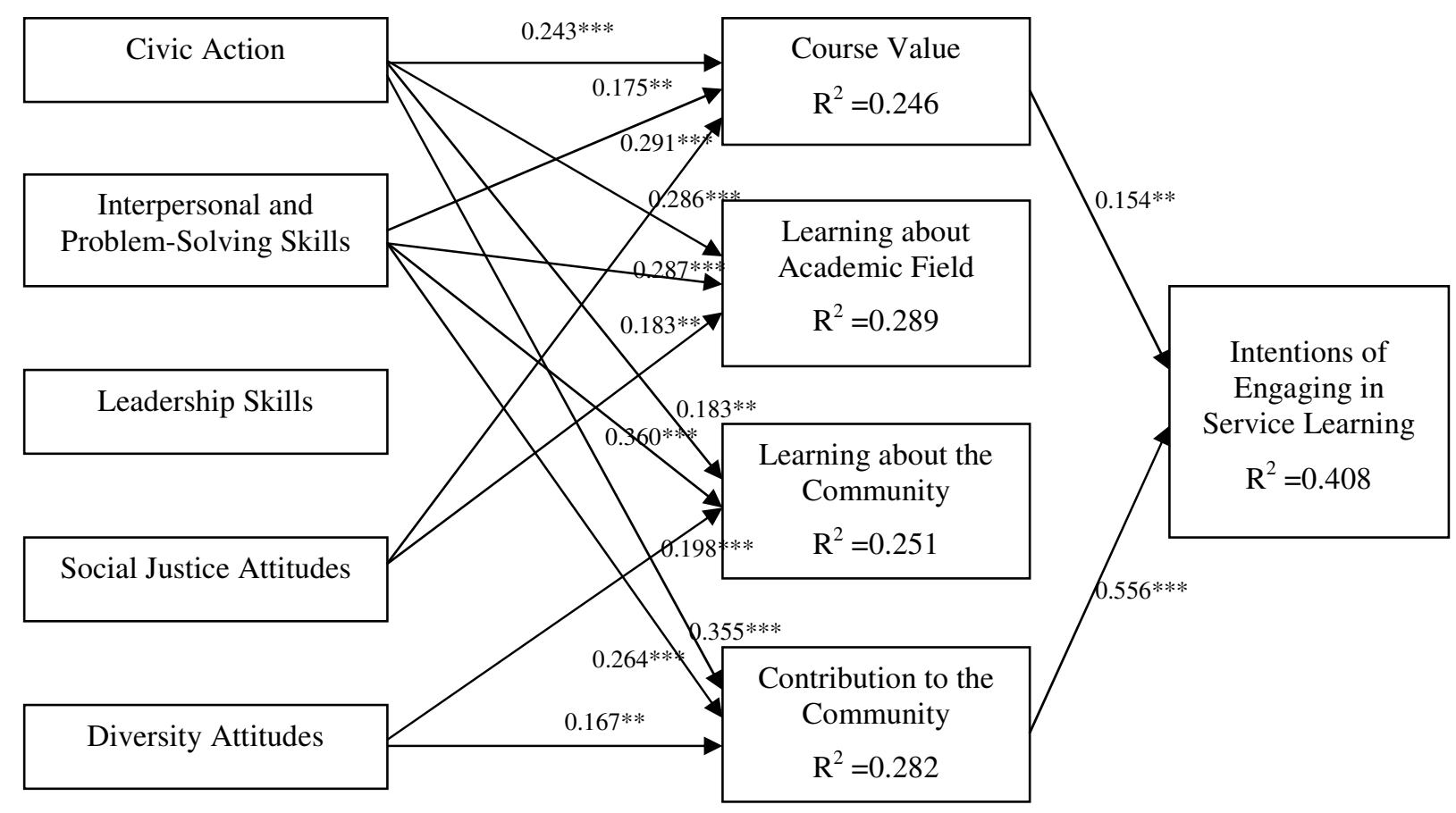

$* * * \mathrm{p}<0.01 * * \mathrm{p}<0.05 * \mathrm{p}<0.1$

Figure 2. Service Learning Adoption Model

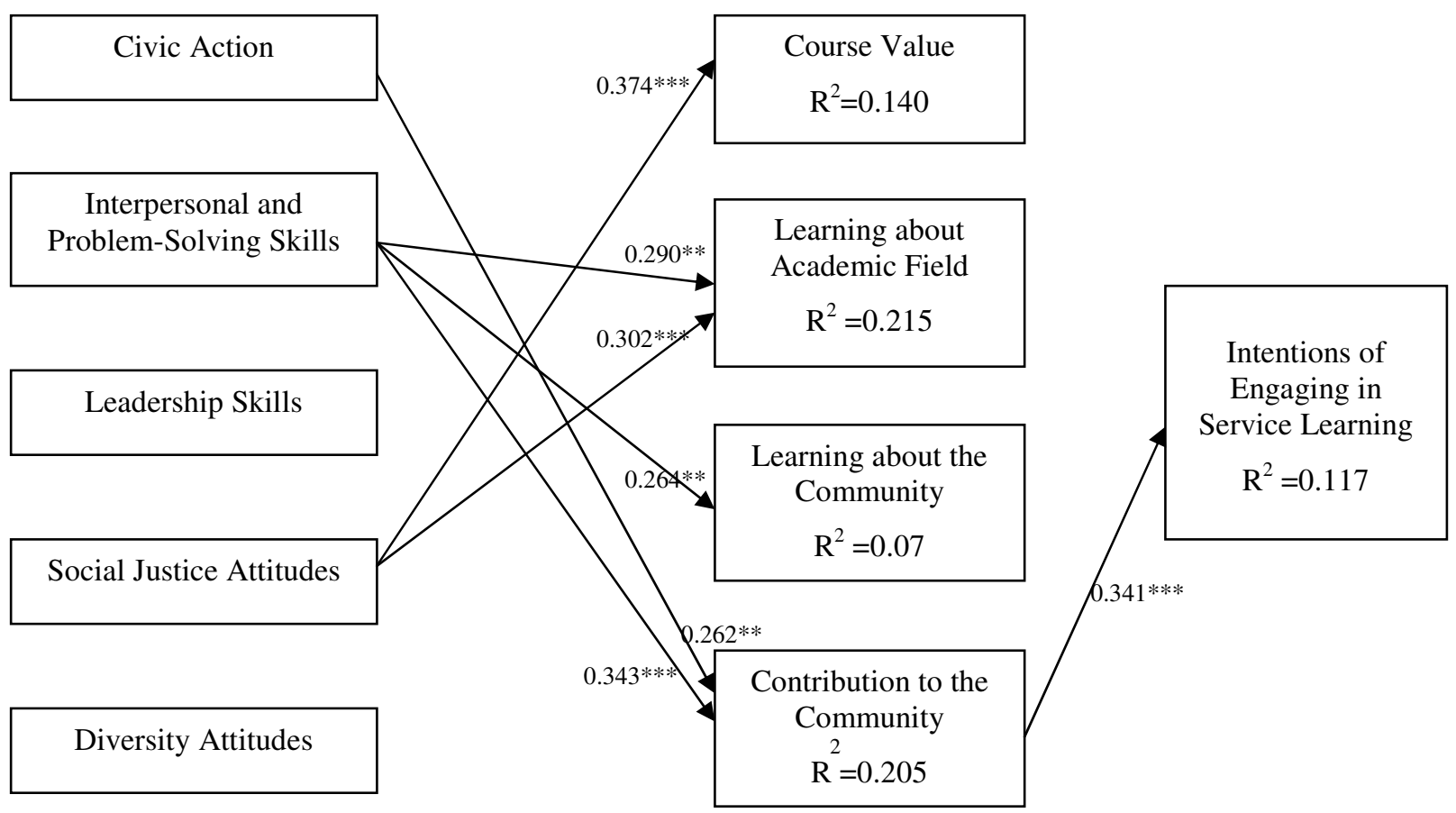

$* * * \mathrm{p}<0.01 * * \mathrm{p}<0.05 * \mathrm{p}<0.1$

Figure 3. Service Learning Adoption Model for Non-Service-Learning Students 


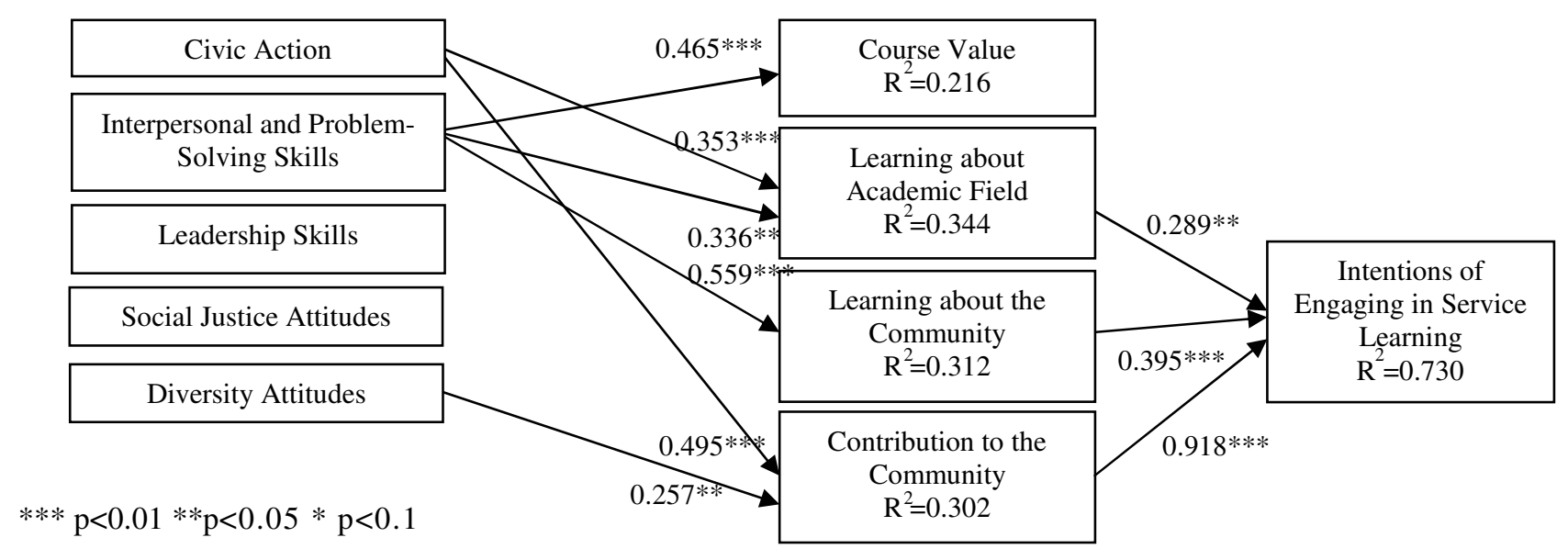

Figure 4. Service Learning Adoption Model for Service-Learning Students

However, for service-learning students, civic action has a significant, direct effect on learning about academic field and contribution to the community. Interpersonal and problem-solving skills are positively associated with course value, learning about academic field, and learning about the community. Diversity attitudes are significantly related to contribution to the community. Learning about the academic field, learning about the community and contribution to the community influence students' continued intentions of engaging in service learning. Service learning adoption models have differences between service-learning and nonservice-learning students. Therefore, $\mathrm{H} 3$ is supported.

\section{CONCLUSIONS}

The analytical results of our investigation indicate a significant and meaningful relationship between civic attitudes and skills and course satisfaction as well as between course satisfaction and students' intention of engaging in service learning. Moreover, service learning adoption models have differences between service-learning and non-service-learning students. Information obtained from experience over a period of time undoubtedly has the potential to modify future intentions of engaging in service learning. Contribution to the community is the only predictor of non-service-learning students' intention of engaging in service learning in the future. However, for service-learning students' continued intentions, learning about academic field, learning about the community and contribution to the community are better predictors than course value.

The comparison between students with different civic attitudes and skills provides an interesting insight into students' acceptance of service learning courses. Our findings indicate that for organizations wanting to promote service learning, the first step is for management to create an awareness of the importance of altruism. To promote the acceptance of service learning on their students, it is important for instructors to crystallize the altruistic behaviors for their students while at the same time providing a rich learning experience.

\section{REFERENCES}

1. Ann M. McCarthy \& Mary L. Tucker. (1999). Student attitudes toward service-learning: implications for implementation Journal of Management Education, 23(5), 554-573.

2. Bagozzi, R.P. \& Y. Yi, (1988). On the evaluation of structure equations models, Academic of Marketing Science, 16, 76-94.

3. Boss, J. (1994). The effect of community service work on the moral development of college ethics students, Jrnl of Moral Education, 23, 183-198.

4. Friedman, S. D. (1996). Community involvement projects in Wharton's MBA curriculum, Jrnl of Business Ethics, 15, 95-101.

5. Kolenko, A., Porter, G., Wheatley, W., \& Colby, M. (1996). A critique of service learning projects in management education: pedagogical foundations, barriers, and guidelines, Journal of Business Ethics, 15, 133-142.

6. Neter, J., Wasserman, W., dc Kutner, M. H. (1985). Applied linear statistical models, Homewood, IL: Irwin.

7. Zlotkowski, E. (1996). Opportunity for all: linking service-learning and business education, Journal of Business Ethics, 15, 5-19. 